\section{Deborah Dunsire}

In under three years, Deborah Dunsire transformed Millennium Pharmaceuticals from an unprofitable company to Takeda's oncology centerpiece. What's next?

Millennium Pharmaceuticals, once the hottest genomics play on Wall Street, was hemorrhaging money and struggling for a new identity when Deborah Dunsire took the helm in July 2005. The company's stock had plunged from its historical high of $\$ 80$ a share to less than $\$ 10$, yet Dunsire saw in Millennium exactly what she wanted: a company dedicated to innovation in oncology and inflammation. She was impressed by the company's pipeline potential and the sophistication of the science. She liked the fact that integrity, ethics and diversity fueled the corporate culture. Moreover, after 17 years of building franchises for Swiss pharmaceutical giant Novartis, Dunsire was ready to spread her wings and shape her own company.

After graduating from medical school at the University of Witwatersrand in Johannesburg, South Africa, Dunsire segued into clinical research and ultimately joined Novartis (at the time, Sandoz). While there, she had a pivotal role in the development and launch of several highly successful products, including the breakthrough cancer drug Gleevec.

"When I met Deborah for the first time, we were at a hotel restaurant at Newark Airport, sitting near the kitchen where nobody could see us," recalls Mark Levin, who founded Millennium in 1993 and served as its CEO until Dunsire took over. "I told her we were looking for that unique combination of passion for making a difference in patients' lives, strong leadership, commercial experience-all within someone committed to building an integrated biopharmaceutical company. Within a few minutes of talking to her, I knew we had our woman," he says.

Dunsire was equally impressed. "The final component to my decision to join was meeting the people — the board, Mark Levin and the management team. I was very impressed by their caliber," Dunsire explains. "However, I told them that while they had something incredibly valuable, it was not in the best shape," she confides.

"It was as if [Millennium] had a wondrous piece of jewelry that had fallen off the dresser and become terribly dusty," explains Dunsire. "You have to pick it up and dust it off, make sure the stones are in place and the clasp repaired-put it back into good shape from the raw materials."

For Dunsire that meant making some very tough decisions, including a drastic reduction in R\&D spending that resulted in the loss of jobs for some top-notch people who had made quite a contribution to the company. "That was a very difficult thing for a company to go through," explains Dunsire. "But the people in the company were saying, 'help us, we know we have to do things differently', so there was real openness from the beginning."

Anna Protopapas, Millennium's senior vice president of corporate development and a veteran of 11 years, confirms, "From the start, Deborah Dunsire recognized what needed to happen and also what was unique about Millennium. She very much cherishes and continues to develop the focus on science, talent and a culture that is entrepreneurial."

In Dunsire's own estimate, the company's greatest achievements during her tenure have evolved around rescoping discovery and augmenting commercialization. Velcade, the company's flagship cancer drug, received approval on 20 June from the US Food and Drug Administration to be used in an additional indication: patients with previously untreated multiple myeloma. Velcade, which is already available to patients in second- and third-line settings, is also the only agent ever on its own to give patients a survival advantage.
Not everyone has perceived Velcade and its promise in so positive a light. Keith Robison, who spent ten years at Millennium and has since created a blog called, "OMICS! OMICS!" (http://omicsomics.blogspot. $\mathrm{com} /$ ) had this to say about the company's prospects in his May 2007 post: "Millennium continues to plow cash into Velcade trials in the hopes of hitting a significant jackpot; multiple myeloma and mantle cell lymphoma are important but won't drive sales into the stratosphere."

Worldwide sales of Velcade in 2007 were nearly $\$ 800$ million and on their way to $\$ 1$ billion in 2008 . Perhaps not stratospheric, but certainly enough to catch the attention of Japan's largest and most venerable pharmaceutical company, Osaka-based Takeda.

Takeda's swift and successful courtship of Millennium is now etched in the history of biotech as one of the sweetest deals ever. Velcade's ascent was certainly part of the attraction, but so, too, was Dunsire. Takeda's President, Yasuchika Hasegawa, was immediately impressed. "Deborah Dunsire is an accomplished physician, scientist and business leader. Along with her seasoned management team, she has created an entrepreneurial and innovative culture that is synergistic with Takeda's own values and culture."

Dunsire is also a great dealmaker who knows the value of her company. She recalls, "Millennium was in such a healthy place with Velcade and the pipeline advancing. The balance was restored. We had turned the analyst community around, and we had six or seven

\section{"It was as if [Millennium] had a wondrous piece of jewelry that had fallen off the dresser and become terribly dusty."}

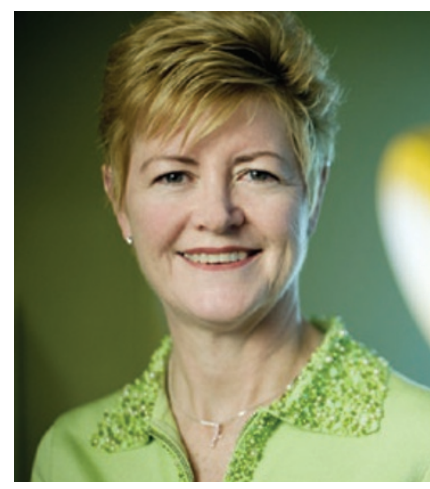

buys on the stock. We were planning to expand and bring in products, and to that end, Anna Protopapas and I went to Japan in July 2007 seeking partnerships. We saw nine companies, one of which was Takeda."

Just a few months later, Dunsire had an unsolicited acquisition proposal on the table. Hasegawa saw a terrific fit and an accelerator for reaching his own company's bold goal of being one of the top three oncology players worldwide by 2020. Thus, Takeda made Millennium an offer that was impossible to refuse.

Now, says Hasegawa, “Millennium is positioned as Takeda's center of excellence in oncology and will take the lead in developing products not only from its own research efforts but also oncology products discovered in Takeda's other research laboratories."

The newly minted oncology powerhouse-to-be is up and running. Enrollment for a pivotal phase 3 trial for Velcade against non-Hodgkin's lymphoma is complete. The company also has another proteasome inhibitor-expected to have a broader range of activity than Velcade and to work as an oral formulation — coming up for an investigational new drug application later this year. It is 1 of 17 drugs in what is now Millennium: The Takeda Oncology Company. That's a formidable management challenge. But Dunsire likes her challenges that way.

Crispin Littlehales, Covelo, California 